\title{
Characterization and Metal Detoxification Potential of Moderately Thermophilic Bacillus cereus from Geothermal Springs of Himalaya
}

\author{
Aslam Khan Ghalib, Muhammad Yasin" and Muhammad Faisal \\ Department of Microbiology and Molecular Genetics; University of the Punjab; Lahore - Pakistan
}

\begin{abstract}
Two thermophilic Bacillus cereus strains (B. cereus-TA2 and B. cereus-TA4) used in the present study were isolated from the geothermal spring of Hunza valley, Gilgit, Pakistan. They showed the ability to withstand and grow at high temperature $\left(85^{\circ} \mathrm{C}\right)$. Both these strains could resist multiple metals (copper, cadmium, mercury, manganese, zinc, arsenic, chromium and selenium). Strain B. cereus-TA4 reduced Cr (VI) at pH 5.0 to 9.0 but maximum reduction

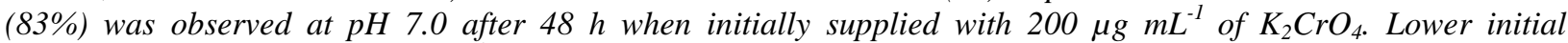

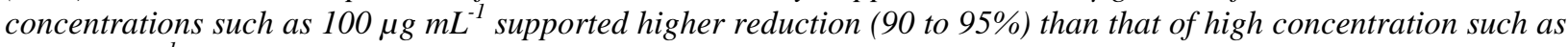
$500 \mu \mathrm{g} \mathrm{mL} L^{-1}$ (20 to 30\%). Both the strains reduced nearly $70 \%$ of Se (IV) after 48 h of growth at pH 7.0 when initially supplied with $200 \mu \mathrm{g} \mathrm{mL} \mathrm{L}^{-1}$ of $\mathrm{Na}_{2} \mathrm{SeO}_{3}$. The optimum temperature for maximum $\mathrm{Se}$ (IV) reduction was $45^{\circ} \mathrm{C}$ for both the strains.
\end{abstract}

Key words: chromium, bioremediation, selenium, heavy metals

\section{INTRODUCTION}

Vast scientific and technological development in the modern world has alos brought numerous challenges in the field of environmental protection and its management (Bennett et al. 2003). Metals such as copper, chromium, mercury, lead, zinc, nickel, arsenic and selenium are considered as the major environmental contaminants (Pekey et al. 2010). They can cause serious problems to the organisms when present above certain level. Chromium is considered as non-essential and toxic metal for the microorganisms and plants while it regulates glucose utilization in the animals (Shelnutt et al. 2007). The wide-spread industrial use of $\mathrm{Cr}$ has caused a serious environmental concern. Chromium exists in nature as $\mathrm{Cr}$ (III) and $\mathrm{Cr}$ (VI); both differ in terms of mobility, bioavailability and toxicity. $\mathrm{Cr}$ (III) is an essential micronutrient for normal glucose utilization in the animals (Krikorian et al. 2010). Hexavalent chromium is highly soluble, more mobile and is the most toxic form of chromium known. It is necessary to convert this carcinogenic form of chromium ( $\mathrm{Cr} \mathrm{VI}$ ) to less mobile and less toxic trivalent chromium. Chemical reduction of hexavalent form into trivalent form is a known method employed for chromate decontamination (Bewley and Clarke 2010; Cismasiu 2011). Nowa-days, microorganisms, especially bacteria are considered as good option for the conversion of hexavalent form into trivalent form (Liao et al. 2014).

Another metal, which has become the element of interest to many investigators because of its toxicological and physiological importance is

*Author for correspondence: yasin_mmg@yahoo.com 
selenium. Selenium exists in the soil as trace element and is very important component of human diet, while its high concentration is toxic (Rayman 2000). Three forms of selenium (selenate, selenite and elemental selenium) are more prominent in nature. Selenate and selenite are toxic while elemental selenium being the insoluble in water is less mobile and usually remains in the soils posing a smaller risk to the environment (Fesharaki et al. 2010). Biological methods for the remediation of toxic forms of chromium and selenium are environment friendly (Hunter 2007; Hunter and Manter 2008; Verma et al. 2009). Bioremediation is inexpensive and established technology, which is commonly used in the environment without posing any damaging effects to the ecosystem (Khan et al. 2009).

The purpose of this study was to isolate novel microbes, especially from some extreme environment and to utilize them for the bioremediation of chromium and selenium polluted soils and wastewater.

\section{MATERIALS AND METHODS}

\section{Bacterial isolation and characterization}

Bacterial strains used in this study were isolated from the northern hilly $(8200 \mathrm{ft})$ geothermal springs of Hunza Gilgit, Pakistan. Water and soil samples were collected and transported to the laboratory in controlled conditions. Some physicochemical parameters such as water temperature $\left(65^{\circ} \mathrm{C}\right), \mathrm{pH}(6.5)$ and air temperature $\left(2^{\circ} \mathrm{C}\right)$ were recorded on the spot. Water and soil samples were diluted and spread on nutrient agar plates and incubated at different temperatures. After $24 \mathrm{~h}$, different colonies of strains were picked and purified. The strains were basically characterized morphologically and biochemically following Gerhardt et al. (1994). The effect of temperature and $\mathrm{pH}$ on bacterial growth was studied by growing the strains in nutrient broth at $45,55,65$, 75 and $85^{\circ} \mathrm{C}$ and $\mathrm{pH} 5.0,7.0$ and 9.0 for $24 \mathrm{~h}$. Metal resistance profile of the isolated strains was also determined against copper, cadmium, mercury, manganese, zinc, arsenic, chromium and selenium.

\section{CR (VI) Reduction}

$\mathrm{Cr}$ (VI) reduction by these bacterial strains was evaluated by using the chromate reduction medium $(\mathrm{g} / \mathrm{L})$ tryptone 10 , yeast extract $5, \mathrm{NaCl} 5$, citric acid 1, $\mathrm{Na}_{2} \mathrm{HPO}_{4} 6.9$ (Deleo and Ehrlich 1994). Hexavalent chromium reduction was monitored at 45,55 and $65^{\circ} \mathrm{C}$ and $\mathrm{pH} 5.0,7.0$ and 9.0, incubation times of 48 and $96 \mathrm{~h}$ and initial chromate concentrations of 100,250 and $500 \mu \mathrm{g}$ $\mathrm{mL}^{-1}$. About $250 \mathrm{~mL}$ of chromium reduction media was prepared and inoculated with $1.0 \mathrm{~mL}$ of fresh culture of bacterial strains TA2 and TA4. On regular time period, flasks along with samples were withdrawn and $\mathrm{Cr}$ (VI) reduction was estimated by using 1,5-diphenylcarbazide following Clesceri et al. (1998).

\section{SE (IV) Reduction}

All the selenite reduction experiments were carried out under aerobic conditions. Selenite reduction was monitored at same temperatures, $\mathrm{pH}$, incubation times and initial $\mathrm{Na}_{2} \mathrm{SeO}_{3}$ concentrations as in the above experiment. Two hundred and fifty milliliter of selenite reduction medium was prepared and inoculated with $1.0 \mathrm{~mL}$ of fresh culture of bacterial strains TA2 and TA4. Medium was also amended with sodium acetate $2.0 \mathrm{~g} \mathrm{~L}^{-1}$ as carbon source. At 48 and $96 \mathrm{~h}$ incubation, cultures were withdrawn taking 1.0 $\mathrm{mL}$ of sample and centrifuged at $14,000 \mathrm{xg}$ for five min. Brown and Watkinson (1977) method was used for the estimation of selenite reduction in the supernatant. The absorbance was measured at $377 \mathrm{~nm}$ using UV-vis spectrophotometer (Cecil 7200, UK).

\section{S rRNA gene sequencing}

For the exact identification of these strains (TA2 and TA4), ribotyping was carried out. The sequencing services were carried out using Big Dye terminator cycle sequencing kit (Applied Biosynthesis, USA). Sequencing products were resolved on an Applied Biosystems model 13730 $\mathrm{XL}$ automated DNA sequencing system. Then the sequences were analyzed by using BLAST from NCBI web site also by multiple sequence alignments through Clustal W.

\section{Statistical analysis}

Data obtained were statistical analysis by using student package statistical software v11.0.

\section{RESULTS}

\section{Strains isolation and identification}

More than 50 bacterial strains were isolated from the soil and water of geothermal springs of Chillas. 
Two strains, TA2 and TA4 could grow up to a temperature of $90^{\circ} \mathrm{C}$ in nutrient broth and were selected for further study. On the basis of various morphological, biochemical, physiological and 16S rRNA gene sequencing study, both the strains were identified as Bacillus cereus (Table 1). The accession number of strains B.cereus-TA2 and B.cereus-TA4 are GU980764 and GU980765, respectively.

\section{Strains characterization}

Both the strains were Gram positive motile rods and formed the spores under unfavorable conditions (Table 1). These were facultative anaerobes and were able to reduce nitrate. They showed resistances against copper, cadmium, mercury, manganese, zinc, arsenic, chromium and selenium (Table 2) and tolerated $700 \mu \mathrm{g} \mathrm{mL}^{-1}$ of $\mathrm{Cu}, 400 \mu \mathrm{g} \mathrm{mL}^{-1}$ of $\mathrm{Cd}, 1500 \mu \mathrm{g} \mathrm{mL}^{-1}$ of $\mathrm{Mn}, 900$ $\mu \mathrm{g} \mathrm{mL} \mathrm{m}^{-1}$ of As, $600 \mu \mathrm{g} \mathrm{mL} \mathrm{m}^{-1}$ of $\mathrm{Cr}$ and $1000 \mu \mathrm{g}$ $\mathrm{mL}^{-1}$ of Se. B. cereus-TA2 tolerated $200 \mu \mathrm{g} \mathrm{mL}^{-1}$ of $\mathrm{Hg}$ while this was $150 \mu \mathrm{g} \mathrm{mL}^{-1}$ for other strain (Table 2). These strains showed optimum growth at $55^{\circ} \mathrm{C}$ and $\mathrm{pH} 7.0$ (Figs. 1A, B).

Table 1 - Morphological and biochemical characteristics of strains.

\begin{tabular}{|c|c|c|c|c|c|}
\hline \multirow[b]{2}{*}{ Characteristics } & \multicolumn{2}{|c|}{ Strains } & \multirow[b]{2}{*}{ Characteristics } & \multicolumn{2}{|c|}{ Strains } \\
\hline & $\begin{array}{c}\text { Bacillus } \\
\text { cereus-TA2 }\end{array}$ & $\begin{array}{c}\text { Bacillus } \\
\text { cereus-TA4 }\end{array}$ & & $\begin{array}{c}\text { Bacillus } \\
\text { cereus-TA2 }\end{array}$ & $\begin{array}{c}\text { Bacillus } \\
\text { cereus-TA4 }\end{array}$ \\
\hline Colony shape & round & round & Lactose & - & - \\
\hline Colony size (mm) & 3.5 & 4 & Inositol & - & - \\
\hline Cell shape & rods & rods & D-sorbitol & - & - \\
\hline Cell size $(\mu \mathrm{m})$ & $1.2-2.4$ & $1.2-2$ & L-rhamnose & - & - \\
\hline Gram staining & +ve & +ve & D-sucrose & - & - \\
\hline Capsules staining & - & - & D-melibiose & - & - \\
\hline Spore staining & + & + & Amygdalin & - & - \\
\hline Motility & + & + & L-Arabinose & - & - \\
\hline ornithine decarboxylase & - & - & Glucose & + & + \\
\hline Urea & - & - & Oxidase & + & + \\
\hline Arginine dihydrolase & - & - & Catalase & + & + \\
\hline Indole production & - & - & Nitrate reduction & + & + \\
\hline lysine decarboxylase & - & - & $\begin{array}{l}\text { Growth on } \\
\text { MacConkey agar }\end{array}$ & - & - \\
\hline Citrate utilization & + & + & O.F test & F.A & F.A \\
\hline acetoin production & + & + & $\mathrm{H} 2 \mathrm{~S}$ production & - & - \\
\hline gelatin hydrolysis & + & + & Starch hydrolysis & - & - \\
\hline
\end{tabular}

OF, Oxidation fermentation; -, Negative; + , Positive

Table 2 - Heavy metals resistance profile of chromium resistant bacterial strains.

\begin{tabular}{|c|c|c|}
\hline \multirow{2}{*}{$\begin{array}{l}\text { Metals } \\
\text { concentration } \\
\left(\mu \mathrm{g} \mathrm{mL}^{-1}\right)\end{array}$} & \multicolumn{2}{|c|}{ Strains } \\
\hline & $\begin{array}{c}\text { Bacillus } \\
\text { cereus-TA2 }\end{array}$ & $\begin{array}{c}\text { Bacillus } \\
\text { cereus-TA4 }\end{array}$ \\
\hline $\mathrm{Cu}$ & 700 & 700 \\
\hline Cd & 400 & 400 \\
\hline Hg & 200 & 150 \\
\hline Mn & 1500 & 1500 \\
\hline $\mathbf{Z n}$ & 200 & 100 \\
\hline As & 900 & 900 \\
\hline $\mathrm{Cr}$ & 600 & 600 \\
\hline Se & 1000 & 1000 \\
\hline
\end{tabular}

\section{CR (VI) Reduction}

Both the strains were able to reduced carcinogenic $\mathrm{Cr}$ (VI) into less toxic $\mathrm{Cr}$ (III) aerobically at various $\mathrm{pH}$ and incubation times (Fig. 1C). B. cereus-TA4 reduced $\mathrm{Cr}(\mathrm{VI})$ at $\mathrm{pH} 5.0$ and 9.0 but maximum reduction $(83 \%)$ was observed at $\mathrm{pH} 7.0$ after $48 \mathrm{~h}$ of incubation when initially supplied with $200 \mu \mathrm{g} \mathrm{mL}^{-1} \mathrm{~K}_{2} \mathrm{CrO}_{4}$. Almost same trend was observed after $96 \mathrm{~h}$ incubation period. As both the strains grew at higher temperature, the reduction potential was also observed at various temperatures $\left(45-65^{\circ} \mathrm{C}\right)$. Increasing temperature led to more reduction of hexavalent chromium. The most favorite temperature for optimum chromate reduction was $55^{\circ} \mathrm{C}$ for both the strains (Fig. 1D). But above $55^{\circ} \mathrm{C}$, a slight decrease in the reduction potential in both the strains was recorded. The rate of chromate removal was faster in the early $48 \mathrm{~h}$ after which there was no significant impact on the $\mathrm{Cr}$ (VI) reduction potential of these strains. Figure 2 shows the effects of various initial $\mathrm{Cr}$ (VI) concentrations on the reduction ability of both the strains. Lower initial concentration such as $100 \mu \mathrm{g} \mathrm{mL} \mathrm{m}^{-1}$ supported higher reduction (90 to $95 \%$ ) than high concentration such as $500 \mu \mathrm{g} \mathrm{mL}^{-1}(20$ to $30 \%)$. 


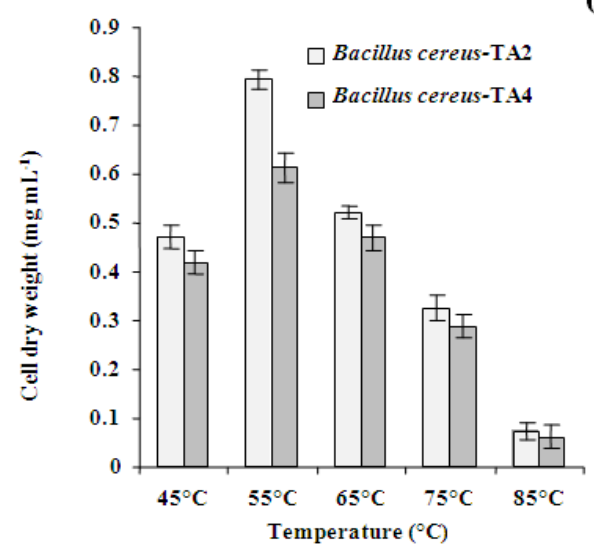

(A)
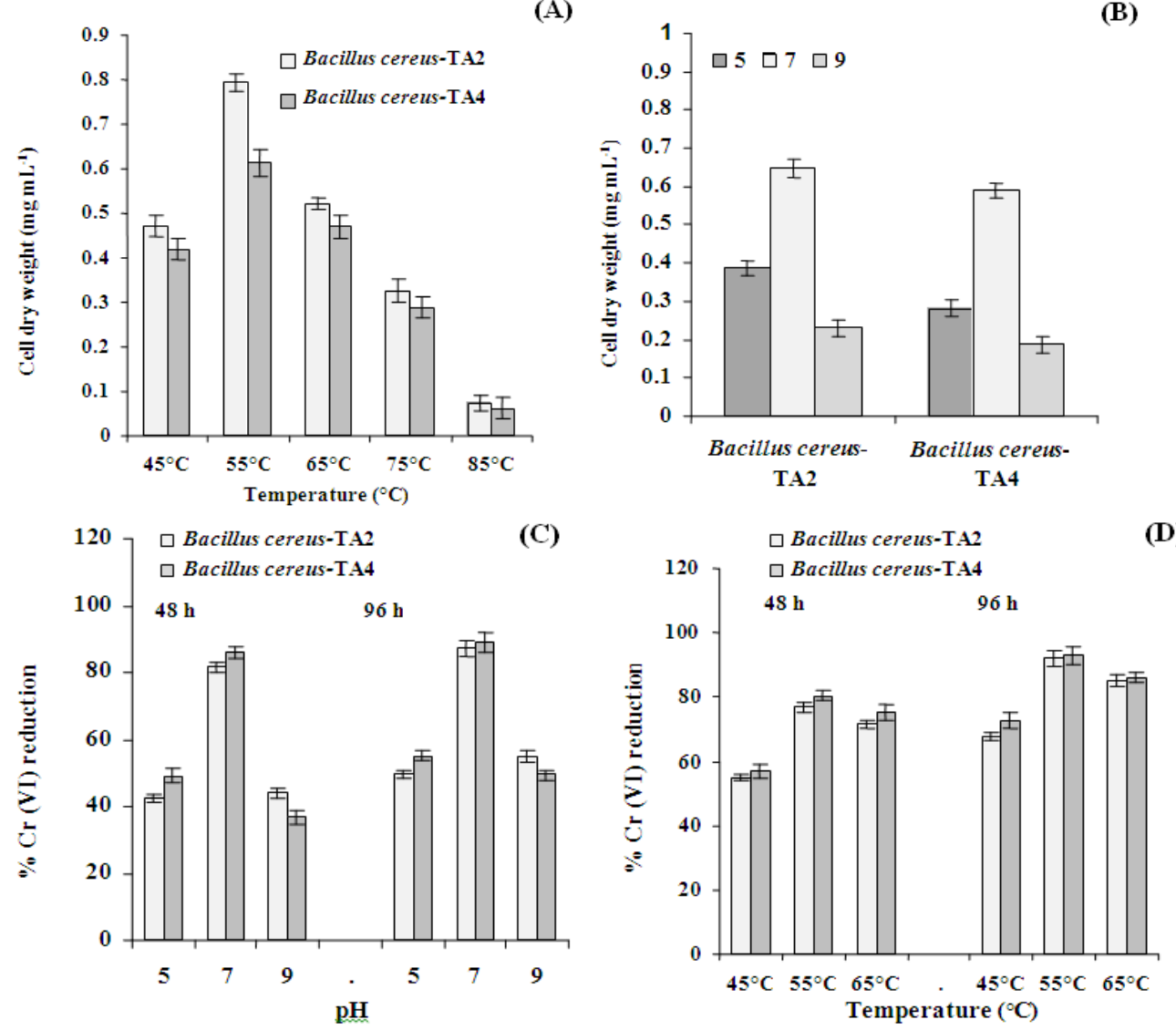

Figure 1 - Growth of strains TA2 and TA4 (A) at 45, 55, 65, 75 and $85^{\circ} \mathrm{C},(\mathrm{B})$ at pH 5.0, 7.0 and 9.0; Reduction of $\mathrm{K}_{2} \mathrm{CrO}_{4}$ (C) at pH 5.0, 7.0 and 9.0 and (D) at 45,55 and $65^{\circ} \mathrm{C}$. Reduction was monitored after 48 and $96 \mathrm{~h}$ of growth incubation. Initial $\mathrm{K}_{2} \mathrm{CrO}_{4}$ concentration used for reduction experiment was $200 \mu \mathrm{g} \mathrm{mL}^{-1}$.

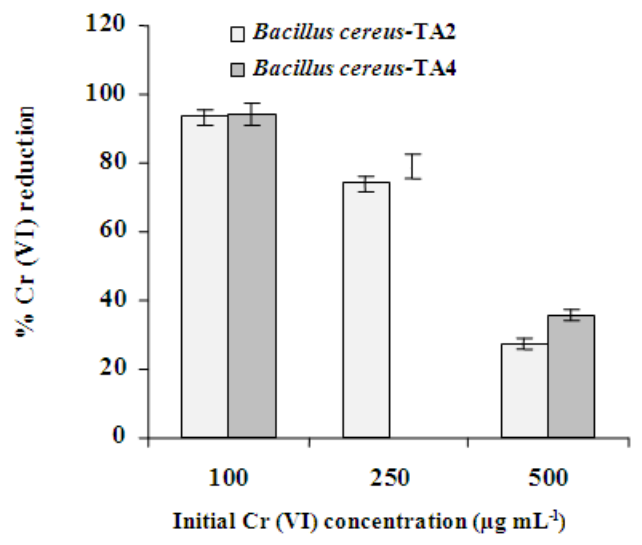

Figure 2 - Reduction of $\mathrm{K}_{2} \mathrm{CrO}_{4}$ at three initial $\mathrm{K}_{2} \mathrm{CrO}_{4}$ concentrations $\left(100,250\right.$ and $\left.500 \mu \mathrm{g} \mathrm{mL}^{-1}\right)$. Reduction was monitored after $48 \mathrm{~h}$ of growth at $\mathrm{pH} 7.0$ and $55^{\circ} \mathrm{C}$.

\section{SE (IV) REDUCTION}

Results showed that both the strains had reduced selenite into elemental selenium under aerobic conditions (Fig. 3). Reduction of selenite was more at $\mathrm{pH} 7.0$ as compared to the other $\mathrm{pH}$ values. Both the strain reduced nearly $70 \%$ of total Se (IV) after $48 \mathrm{~h}$ of growth at pH7.0 (Fig. 3). Interestingly, $\mathrm{Se}$ (IV) reduction potential of the strain TA4 was more at $\mathrm{pH} 5.0$ and 9.0 than at pH7.0 after 48 and $96 \mathrm{~h}$ as compared to the strain TA2. The optimum temperature for maximum Se (IV) reduction was $45^{\circ} \mathrm{C}$ for both the strains. As seen from Figure 4, Se (IV) reduction occurred at various initial selenite concentrations (100 to 500 $\left.\mu \mathrm{g} \mathrm{mL}{ }^{-1}\right)$. The percentage selenite reduction was highest at lowest initial selenite concentrations but the amount of Se (IV) reduced was maximum at highest initial selenite concentration $\left(500 \mu \mathrm{g} \mathrm{mL}^{-}\right.$ $\left.{ }^{1}\right)$. 

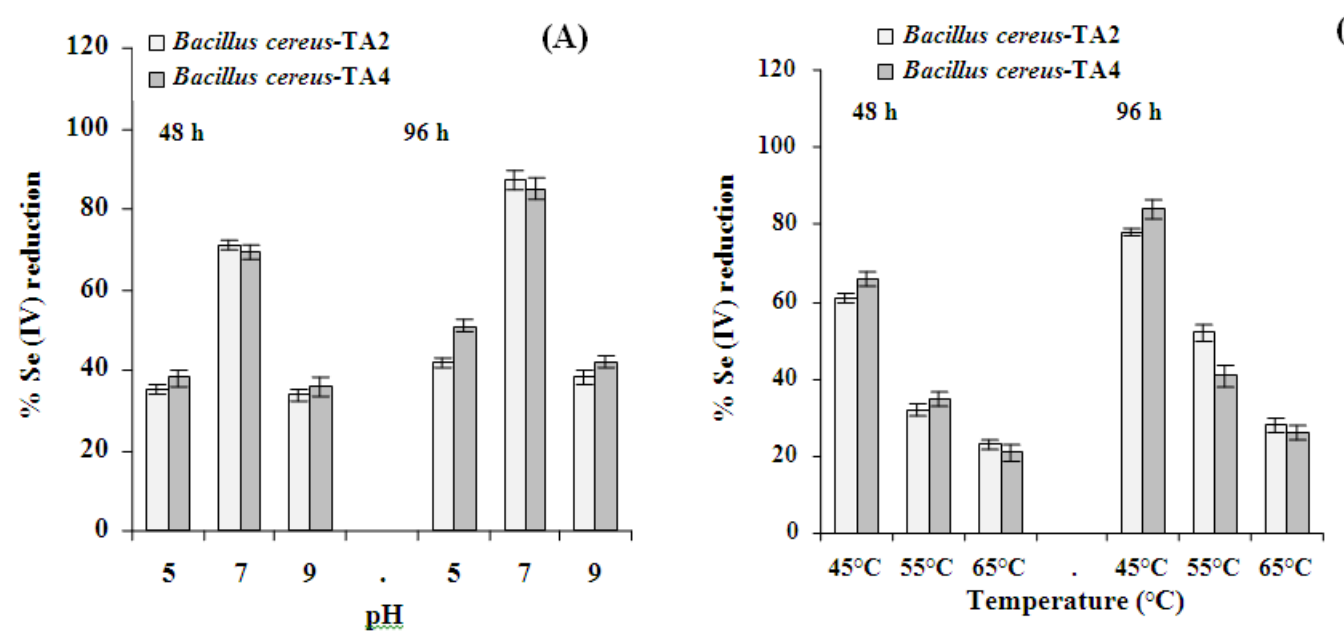

Figure 3 - Reduction of $\mathrm{Na}_{2} \mathrm{SeO}_{3}$ at $\mathrm{pH} 5.0,7.0$ and 9.0 and 45, 55, and $65^{\circ} \mathrm{C}$. Reduction was monitored after 48 and $96 \mathrm{~h}$ of growth. Initial $\mathrm{Na}_{2} \mathrm{SeO}_{3}$ concentration used for reduction experiment was $200 \mu \mathrm{g} \mathrm{mL}^{-1}$.

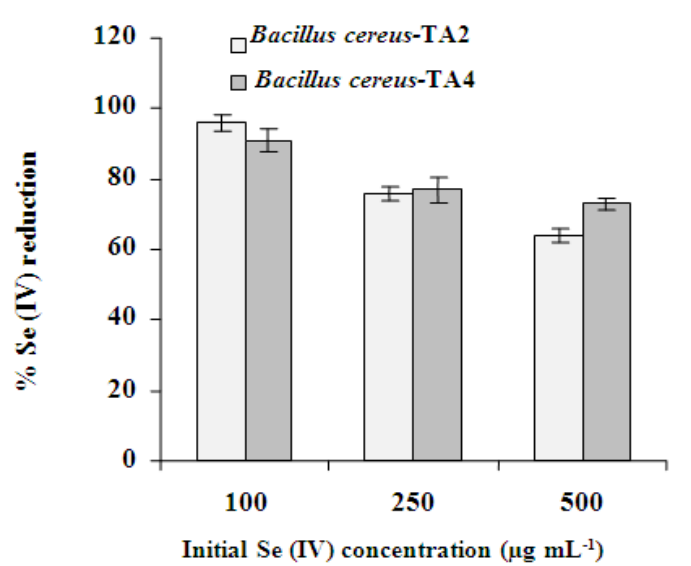

Figure 4 - Reduction of selenite at three initial $\mathrm{Na}_{2} \mathrm{SeO}_{3}$ concentrations $\left(100,250\right.$ and $\left.500 \mu \mathrm{g} \mathrm{mL}^{-1}\right)$. Cultures were harvested after $48 \mathrm{~h}$ of growth at $\mathrm{pH} 7.0$ and temperature $55^{\circ} \mathrm{C}$.

\section{DISCUSSION}

Present study deals with two metal resistant bacterial strains $B$. cereus-TA2 and B. cereusTA4, which were isolated from the hot spring of Hunza valley, Gilgit (Himalayan range), Pakistan. Both these strains had the ability to tolerate and reduce chromium and selenium simultaneously. Interestingly, the strains were isolated from a place, which was not previously or presently contaminated with heavy metals (chromium and selenium) due to anthropogenic activity. Dib et al.
(2008) also reported bacterial strains from high altitude having extreme environment (above 4400 $\mathrm{m})$, which showed arsenic resistance. Both these strains were Gram positive facultative anaerobic motile rods and had the ability to reduce the nitrate. They showed multiple metals resistances, which could be an important property to use these strains to perform better in polluted wastewater for its treatment. In another study, a metal resistant Halomonas was isolated, which tolerated multiple metals (chromate, cobalt, zinc, copper and cadmium) (Osman et al. 2010). Hong et al. (2010) also reported three strains of Fusarium solani, which not only showed resistance to copper but also resistant to zinc and this ability showed promising results for the treatment of zinc, copper and pyrene from polluted wastes. Both these strains (B. cereus-TA2 and B. cereus-TA4) showed growth over a wide range of $\mathrm{pH}$ and temperature but maximum growth was observed at $55^{\circ} \mathrm{C}$ at $\mathrm{pH} 7.0$.

The enzyme, which is responsible for $\mathrm{Cr}$ (VI) reduction in both these strains might be active at very high temperature. Eberly and Ely (2008) isolated a set of hydrogenases from thermophilic microorganisms, which showed their activity from 50 to $125^{\circ} \mathrm{C}$ and could be exploited for bioremediation, biosensors and for $\mathrm{H}_{2} \mathrm{~S}$ production. In this study, for both the strains, maximum $\mathrm{Cr}(\mathrm{VI})$ reduction occurred at $55^{\circ} \mathrm{C}$ and pH7.0. Opperman and Heerdan (2007) studied 
aerobic conversion of carcinogenic hexavalent chromium in a complex organic medium by thermophilic Thermus scotoductus SA-01. The temperature and $\mathrm{pH}$ for optimum $\mathrm{Cr}(\mathrm{VI})$ reduction was $80^{\circ} \mathrm{C}$ and 7.0 , respectively. In both the strains, the reduction rate was not affected up to $250 \mu \mathrm{g}$ $\mathrm{mL}^{-1}$ of $\mathrm{K}_{2} \mathrm{CrO}_{4}$ but at higher initial $\mathrm{Cr}$ (VI) concentration up to $500 \mu \mathrm{g} \mathrm{mL}^{-1}$, reduction was decreased significantly (64\%). Chromate-resistant bacterial mechanisms have been reported either due to plasmids or by chromosomal encoded genes (Cervantes and Campos-Garcia 2007). The efflux of chromate from cytoplasm through membrane transporter in bacterial cells was encoded on the genes present on plasmids. The chromate reduction strategies like free-radical detoxifying activities, repairing of DNA damage, specific or unspecific $\mathrm{Cr}$ (VI) reduction are under the control of genes, which are present on chromosome (Pimentel et al. 2002).

The strains B. cereus-TA2 and B. cereus-TA4 also reduced selenite to elemental selenium aerobically at an initial selenite concentration of $200 \mu \mathrm{g} \mathrm{mL}^{-1}$. But unlike chromate, maximum reduction was observed at $45^{\circ} \mathrm{C}$ in case of selenium. It showed that the selenite reductase enzymes/protein involved in selenite reduction worked optimally at $45^{\circ} \mathrm{C}$. Others investigators have also studied the reduction of selenite to elemental selenium by bacteria such as Azospira oryzae, Rhizobium sullae and Tetrathiobacter kashmirensis.

\section{CONCLUSION}

Results showed that both these thermotolerant strains isolated from the hot spring of Hunza valley, Gilgit, Pakistan not only were resistant to a variety of metals and also gave promising results in the bioremediation of toxic chromate and selenite.

\section{ACKNOWLEDGEMENT}

Higher Education Commission and University of the Punjab, Lahore, Pakistan is greatly acknowledged for financial support for this research work.

\section{REFERENCES}

Bennett LE, Burkhead JL, Hale KL, Terry N, Pilon M, Pilon-Smits EH. Analysis of transgenic Indian Mustard plants for phytoremediation of metals contaminated mine tailings. J Environ Qual. 2003; 32: 432-440.

Bewley RJF, Clarke S. Field application of calcium polysulphide for ex situ treatment of soils contaminated with chromite ore processing residue. Land Contam Reclam. 2010; 18: 1-12.

Brown MW, Watkinson JH. An automated fluorimetric method for determination of nanogram quantities of selenium. Analytica Chimica Acta. 1977; 89: 29-35.

Cervantes C, Campos-Garcia J. Reduction and efflux of chromate by bacteria. In: Nies DH, Silver S, editor. Molecular Microbiology of Heavy Metals. Berlin: Springer-Verlag; 2007. P. 407-420.

Cismasiu CM. The adaptation of gram-negative bacteria to acidic environmental conditions with implication in heavy metals removal processes. Rom Biotech Lett. 2011; 16: 10-18.

Clesceri SI, Greenberg A, Eaton AD. Standard methods for the examination of water and waste water. American Public Health Association, Washington, D. C; 1998.

Deleo PC, Ehrlich HL. Reduction of hexavalent chromium by Pseudomonas fluorescens LB 300 in batch and continuous cultures. Appl Microbiol Biotechnol. 1994; 40: 756-759.

Dib J, Motok J, Zenoff V, Ordoñez O, Farías M. Occurrence of resistance to antibiotics, UV-B, and arsenic in bacteria isolated from extreme environments in high-altitude (above 4400m) Andean wetlands. Curr Microbiol. 2008; 56: 510-517.

Eberly J, Ely R. Thermotolerant hydrogenases: Biological diversity, properties, and biotechnological applications. Crit Rev Microbiol. 2008; 34: 117-130.

Fesharaki PJ, Nazari P, Shakibai M, Rezaie S, Banoee M, Abdollahi M, Shahverdi AR. Biosynthesis of selenium nanoparticles using Klebsiella pneumoniae and their recovery by a simple sterilization process. Braz J Microbiol. 2010; 41: 461-466.

Gerhardt P, Murry RGE, Wood WA, Kreig NR. Methods for general and molecular bacteriology. American Society for Microbiology, Washington, D.C; 1994.

Hong JW, Park JY, Gadd GM. Pyrene degradation and copper and zinc uptake by Fusarium solani and Hypocrea lixii isolated from petrol station soil. J Appl Microbiol. 2010; 108: 2030-2040.

Hunter W. An Azospira oryzae (syn Dechlorosoma suillum) strain that reduces selenate and selenite to elemental red selenium. Curr Microbiol. 2007; 54: 376-381. 
Hunter W, Manter D. Bio-Reduction of selenite to elemental red selenium by Tetrathiobacter kashmirensis. Curr Microbiol. 2008; 57: 83-88.

Khan MS, Zaidi A, Wani PA, Oves M. Role of plant growth promoting rhizobacteria in the remediation of metal contaminated soils. Environ Chem Lett. 2009; 7: 1-19.

Krikorian EJC, Boespflug EL, Nash TA, Shidler MD. Improved cognitive-cerebral function in older adults with chromium supplementation. Nutrit Neurosci. 2010; 13: 116-122.

Liao Y, Min X, Yang Z, Chai L, Zhang S, Wang Y. Physicochemical and biological quality of soil in hexavalent chromium-contaminated soils as affected by chemical and microbial remediation. Environ Sci Pollut Res. 2014; 21: 379-388.

Opperman DJ, Van-Heerden E. Aerobic $\mathrm{Cr}(\mathrm{VI})$ reduction by Thermus scotoductus strain SA-01. J Appl Microbiol. 2007; 103: 1907-1913.

Osman O, Tanguichi H, Ikeda K, Park P, Tanabe-Hosoi S, Nagata S. Copper-resistant halophilic bacterium isolated from the polluted Maruit Lake, Egypt. J Appl Microbiol. 2010; 108: 1459-1470.
Pekey B, Bozkurt ZB, Pekey H, Doğan G, Zararsiz A, Efe $\mathrm{N}$, Tuncel $\mathrm{G}$. Indoor/outdoor concentrations and elemental composition of PM10/PM2.5 in urban/industrial areas of Kocaeli City, Turkey. Indoor Air. 2010; 20: 112-125.

Pimentel BE, Moreno-Sanchez R, Cervantes C. Efflux of chromate by Pseudomonas aeruginosa cells expressing the ChrA protein. FEMS Microbiol Lett. 2002; 212: 249-54.

Rayman MP. The importance of selenium to human health. Lancet. 2000; 356: 233-241

Shelnutt SR, Goad P, Belsito DV. Dermatological toxicity of hexavalent chromium. Crit Rev Toxicol. 2007; 37: 375-387.

Verma T, Garg SK, Ramteke PW. Genetic correlation between chromium resistance and reduction in Bacillus brevis isolated from tannery effluent. J Appl Microbiol. 2009; 107: 1425-1432.

Received: May 22, 2013; Accepted: November 04, 2013. 